\title{
FGFR1 Gene Mutation Negative
}

National Cancer Institute

\section{Source}

National Cancer Institute. FGFR1 Gene Mutation Negative. NCI Thesaurus. Code C160361.

A genetic finding indicating that FGFR1 gene mutations have not been detected in a sample. 